\title{
ROLE OF THE NAPHTHOQUINONE MOIETY IN THE BIOLOGICAL ACTIVITIES OF SAKYOMICIN A
}

\author{
Yukinori Take, Masako Sawada, Hironori Kunai, Yoshio Inouye \\ and SHOSHIRO NAKAMURA \\ Institute of Pharmaceutical Sciences, \\ Hiroshima University School of Medicine, \\ 1-2-3 Kasumi, Minami-ku, Hiroshima 734, Japan
}

(Received for publication December 26, 1985)

\begin{abstract}
The naphthoquinone moiety was proven to be essential to the biological activities of sakyomicin A using various naphthoquinone derivatives. Among the naphthoquinones tested, juglone (5-hydroxy-1,4-naphthoquinone) which resembles the partial structure of sakyomicin A was the most active in cytotoxicity against murine lymphosarcoma L5178Y cells, electron acceptor function in the oxidation of NADH by Clostridium kluyveri diaphorase or rat liver mitochondria and inhibition against avian myeloblastosis virus reverse transcriptase. The significantly lower cytotoxicity of sakyomicin A as compared with juglone was attributable to its poor membrane transport. The inhibition of reverse transcriptase activity may result from the interaction between a sulf hydryl group in the active center of the enzyme and quinone groups of the naphthoquinones and sakyomicin $\mathrm{A}$.
\end{abstract}

Retroviruses contain an enzyme called reverse transcriptase, which is responsible for the first step of the integration of viral genomes into cellular DNA, and agents which inhibit this enzyme are therefore of potential therapeutic use against viral infection.

In the course of our screening for the enzyme inhibitors against reverse transcriptase of avian myeloblastosis virus (AMV), novel substances, retrostatin ${ }^{1)}$ and chromostin ${ }^{2)}$, and limocrocin ${ }^{3)}$ which had been reported as a pigment produced by Streptomyces limosus ${ }^{4)}$ were isolated as the specific enzyme inhibitors. Furthermore, one of the active metabolites of Streptomyces origin was proven to be identical with sakyomicin $\mathrm{A}^{5)}$, an antibiotic produced by a strain of Nocardia ${ }^{6)}$. Besides an inhibitory activity against reverse transcriptase ${ }^{5)}$, sakyomicin A showed an electron acceptor activity in the oxidation of NADH by bacterial diaphorase or mitochondria ${ }^{7)}$. Similar to streptonigrin which is another potent inhibitor of reverse transcriptase ${ }^{8,9)}$, only a catalytic amount of sakyomicin A was necessary for the oxidation of NADH, though exogenous NADH was oxidized by mitochondria in the presence of sakyomicin A but not streptonigrin. In accordance with the oxidation of $\mathrm{NADH}$, sakyomicin A was reduced to a hydroquinone which, in turn, autoxidized to a quinone accompanying the generation of hydrogen peroxide. In contrast to streptonigrin which had been reported to primarily interfere with oxidative phosphorylation in mitochondria by facilitating the oxidation of NADH by DT-diaphorase $\mathrm{e}^{10 \sim 12)}$, the enzyme involved in sakyomicin A-dependent oxidation of NADH appeared to be in a different compartment in mitochondria from DT-diaphorase.

The present study was undertaken to examine the role of the naphthoquinone moiety in the biological activities of sakyomicin A using various naphthoquinone derivatives.

\section{Materials and Methods}

Materials

Sakyomicin A was kindly donated by Prof. N. TANAKA, Institute of Applied Microbiology, Uni- 
Fig. 1. Structures of the naphthoquinones and sakyomicin A.

\begin{tabular}{clll} 
& & \\
& & & \\
\hline Compound & $\mathrm{R}_{1}$ & $\mathrm{R}_{2}$ & \\
\hline $\mathbf{1}$ & $\mathrm{H}$ & $\mathrm{H}$ & $\mathrm{H}$ \\
$\mathbf{2}$ & $\mathrm{H}$ & $\mathrm{H}$ & $\mathrm{OH}$ \\
$\mathbf{3}$ & $\mathrm{Cl}$ & $\mathrm{Cl}$ & $\mathrm{H}$ \\
$\mathbf{5}$ & $\mathrm{CH}$ & $\mathrm{H}$ & $\mathrm{H}$ \\
$\mathbf{5}$ & $\mathrm{OH}$ & $\mathrm{H}$ & $\mathrm{H}$ \\
$\mathbf{7}$ & $\mathrm{OH}$ & $\left(\mathrm{CH}_{2}\right)_{2} \mathrm{COOH}$ & $\mathrm{H}$ \\
& $\mathrm{OH}$ & $\left(\mathrm{CH}_{2}\right)_{2} \mathrm{COOEt}$ & $\mathrm{H}$ \\
\hline
\end{tabular}

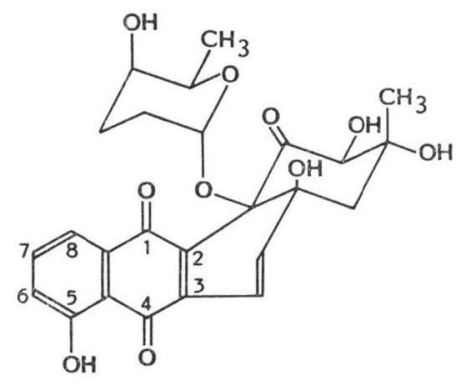

Sakyomicin A

versity of Tokyo. 1,4-Naphthoquinone (1) was obtained from Tokyo Kasei Kogyo Co., Ltd., Tokyo. Juglone (5-hydroxy-1,4-naphthoquinone, 2), 2,3-dichloro-1,4-naphthoquinone (3) and menadione (2methyl-1,4-naphthoquinone, 4) were products of Nakarai Chemicals Ltd., Kyoto. 2-Hydroxy-1,4naphthoquinone (5) was purchased from Aldrich Chemical Co., Inc., Wis. 3-(2-Carboxyethyl)-2hydroxy-1,4-naphthoquinone (6) and 3-(2-ethoxycarbonylethyl)-2-hydroxy-1,4-naphthoquinone (7) were prepared according to the methods of Pettit and HoughtoN ${ }^{13)}$, and Fieser and LeffleR ${ }^{14)}$. Diaphorase from Clostridium kluyveri was purchased from Oriental Yeast Co., Ltd., Tokyo. All other materials were commercial products of the analytical grade.

Assay Methods for Biological Activities

The detailed assay methods for reverse transcriptase and DNA-directed DNA polymerase I of Escherichia coli were described in the previous papers ${ }^{3,8)}$.

Growth inhibitory activity against murine lymphosarcoma L5178Y cells was determined as described previously ${ }^{15)}$.

Determination of Hydrogen Peroxide

Hydrogen peroxide was measured by the oxidative coupling of 4-aminoantipyrine with phenol by horse radish peroxidase to produce a quinone-imine dye with an absorption maximum at $500 \mathrm{~nm}^{16)}$. The details were described in the previous paper $^{7)}$.

\section{Oxidation of NADH or NADPH by Rat Liver Mitochondria}

Rat liver mitochondria were isolated by the method of JOHNSON and LARDY ${ }^{17}$ ) and protein concentrations were determined by the method of LownY et al. ${ }^{18)}$. The oxidation of NADH or NADPH by mitochondria was measured at $30^{\circ} \mathrm{C}$ by oxygen consumption as determined with a Clark type electrode (Yellow Spring Instrument Co., Yellow Spring, Ohio) ${ }^{19)}$.

Respiration of Rat Liver Mitochondria

Respiration of mitochondria on glutamate was measured by the same method as described in the measurement of the oxidation of NADH or NADPH.

\section{Results}

The activity of AMV reverse transcriptase was markedly inhibited by 1, 2, 3 or 4 at $40 \mu \mathrm{g} / \mathrm{ml}$, while moderate inhibition was observed by sakyomicin A and no significant inhibition by either $\mathbf{5 , 6}$ or 7 at the same concentration (Table 1). 2 was the most active among the naphthoquinones tested with more than $80 \%$ inhibition even at $10 \mu \mathrm{g} / \mathrm{ml}$. On the other hand, $\mathrm{ID}_{50}$ of $\mathbf{1}$ and $\mathbf{2}$ against $E$. coli DNAdirected DNA polymerase I were approximately $80 \mu \mathrm{g} / \mathrm{ml}$.

As for cytotoxicity against $\mathrm{L} 5178 \mathrm{Y}$ cells, $\mathrm{ID}_{50}$ of $\mathbf{1 , 2 , 3 , 4}$ and sakyomicin A were $0.089,0.024,0.14$, 
Table 1. Effects of the naphthoquinones and sakyomicin A on AMV reverse transcriptase.

\begin{tabular}{ccc}
\hline Compound & $\begin{array}{c}\text { Concentration } \\
(\mu \mathrm{g} / \mathrm{ml})\end{array}$ & $\begin{array}{c}\text { Inhibition } \\
(\%)\end{array}$ \\
\hline $\mathbf{1}$ & 40 & 85 \\
$\mathbf{2}$ & 10 & 50 \\
& 40 & 94 \\
$\mathbf{3}$ & 10 & 82 \\
& 40 & 76 \\
$\mathbf{4}$ & 10 & 34 \\
& 40 & 77 \\
$\mathbf{5}$ & 10 & 32 \\
& 40 & 0 \\
$\mathbf{6}$ & 10 & 0 \\
& 40 & 0 \\
7 & 10 & 0 \\
& 40 & 0 \\
Sakyomicin A & 10 & 0 \\
& 40 & 63 \\
& 10 & 26 \\
\hline
\end{tabular}

0.39 and $0.48 \mu \mathrm{g} / \mathrm{ml}$, respectively, and those of $\mathbf{5}$, 6 and 7 were much higher than $4.0 \mu \mathrm{g} / \mathrm{ml}$ (Fig. 2).

Generation of hydrogen peroxide in conjunction with the oxidation of NADH or NADPH by C. kluyveri diaphorase is shown in Fig. 3. Hydrogen peroxide was produced in the presence of a catalytic amount of $\mathbf{1}, \mathbf{2}, \mathbf{3}$ or 4 , as was the case with sakyomicin A, whereas no significant effect on the generation of hydrogen peroxide was observed in the presence of $\mathbf{5 , 6}$ or $\mathbf{7}$ even at the highest concentration tested. $\mathbf{2}$ was the most active among the naphthoquinones and the activities of 3 and 4 were comparable to that of $\mathbf{1}$. In general, NADPH was more preferably oxidized by bacterial diaphorase than NADH except for the case of 3 .

Oxygen consumption coupled to the oxidation of NADH or NADPH by isolated rat liver mitochondria is shown in Fig. 4. In well accordance with the results for sakyomicin A, significant enhancement in the oxidation of NADH but not NADPH was observed by adding either $\mathbf{1 , 2}$ or $\mathbf{3}$ to the reaction medium. Though 4 was one of the potent electron acceptors in the oxidation of NADH by bacterial diaphorase, the oxidation of NADH by mitochondria in the presence of 4 was not remarkable.

The effects of the naphthoquinones and sakyomicin A on the oxidation of glutamate by mitochondria are shown in Fig. 5. In contrast to the pattern obtained with sakyomicin A, a rapid but not continuous decline in oxygen content was observed in the presence of $\mathbf{1}$ or $\mathbf{2}$. A steady but not sharp decline was, however, observed in the presence of 4. Again, 5, 6 and 7 exerted no effect on the respiration of mitochondria.

\section{Discussion}

The results presented in this report support the conclusion that the naphthoquinone moiety is es-
Fig. 2. Effects of the naphthoquinones and sakyomicin A on the growth of L5178Y cells.

was diluted with serum-free Fischer's medium to make a test solution.

cell suspension $\left(5.0 \sim 6.0 \times 10^{4}\right.$ cells $\left./ 1.8 \mathrm{ml}\right)$ in Fischer's medium containing $10 \%$ horse serum (Grand Island Biological Co.) was incubated in a

The cell numbers were determined in a Model Dn Coulter counter.

$1 \bigcirc, 2 、 3 \triangle, 4 \Delta, 5 \square, 6$ 圈, $7 \nabla$, sakyomicin A

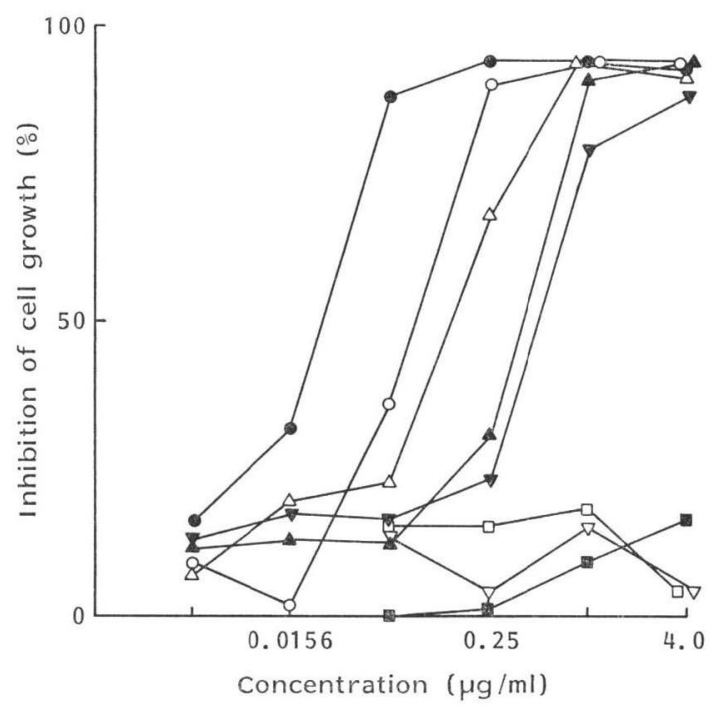


Fig. 3. Generation of hydrogen peroxide coupled to the oxidation of NADH or NADPH by $C$. kluyveri diaphorase.

A mixture of 9.0 units/ml diaphorase, $0.9 \mathrm{~mm}$ NADH (A) or NADPH (B), $0.05 \mathrm{~mm}$ EDTA and $10 \mathrm{~mm}$ Tris- $\mathrm{HCl}(\mathrm{pH} 8.0)$ was incubated with a test sample in a final volume of $1 \mathrm{ml}$ at $37^{\circ} \mathrm{C}$ for 5 minutes.

Hydrogen peroxide formed was measured by the method described previously ${ }^{7}$.

Test samples were dissolved in and diluted with DMSO to adjust the final concentration of DMSO at $1 \%$.

$1 \bigcirc, 2 \bullet, 3 \triangle, 4 \Delta, 5 \square, 6$ 逗, $7 \nabla$, sakyomicin A $\nabla$.
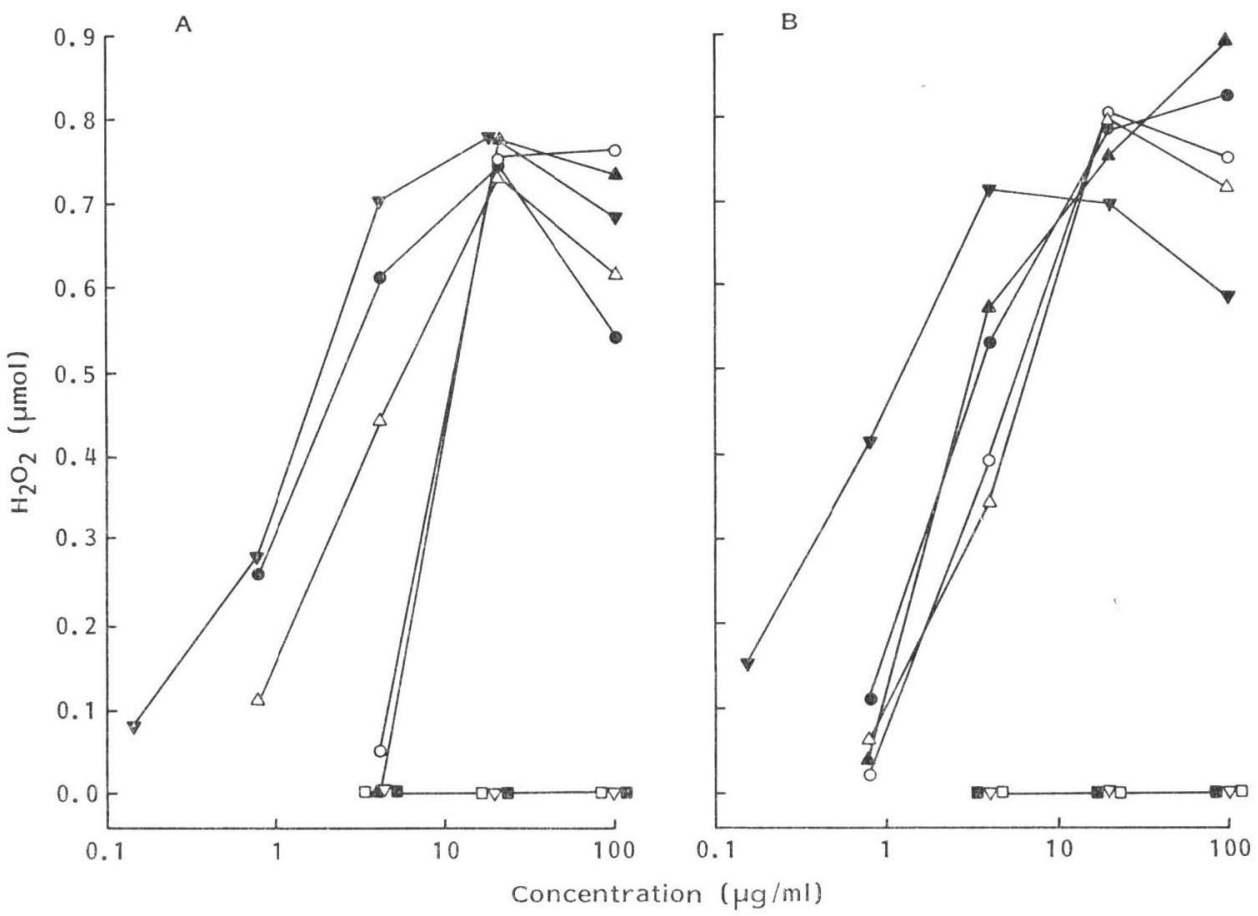

sential to the biological activities of sakyomicin A. Furthermore, the hydroxyl group at C-5 of this moiety might have some responsibility for the enhanced electron acceptor activity of sakyomicin A as suggested by the highest activity of 2 among the naphthoquinones tested. The methyl group at $\mathrm{C}-2$ makes 4 unique; in marked contrast to the result obtained with $\mathbf{1}, \mathbf{2}$ or 3 , no enhanced oxidation of NADH by mitochondria was observed in the presence of $\mathbf{4}$ as can be seen in Fig. 4 . By this fact, it is partially accounted for that $\mathbf{4}$ is much less cytotoxic against L5178Y cells as compared with $\mathbf{1}$ and $\mathbf{3}$ which are as potent electron acceptors as 4 in the oxidation of NADH by bacterial diaphorase. The hydroxyl group at $\mathrm{C}-2$ might abolish the biological activities of 5, 6 and 7 which are inactive in cytotoxicity against L5178Y cells, enhancement of the oxidation of NADH by bacterial diaphorase or mitochondria and inhibition against reverse transcriptase. Although no marked activity was manifested by 6 or 7, the adverse effect of the hydroxyl group at C-2 had been reported to be antagonized by appropriate side chains at C-320). Since the electron acceptor activities of the naphthoquinones are well correlated with their inhibitory activities against reverse transcriptase, a sulfhydryl group in the catalytic center of reverse transcriptase is considered to be highly reactive with their quinone groups as speculated by the others ${ }^{21)}$. This is further confirmed by the fact that $\mathbf{1}, \mathbf{2}, \mathbf{3}$ and $\mathbf{4}$ also inhibited the activity of Alcaligenes creatine amidinohydrolase (creatinase, EC 3.5.3.3) ${ }^{22)}$, another sulf hydryl enzyme, at the same range of drug concentrations (unpublished observation). The bulky structure of sakyomicin A as compared with those of the naphthoquinones might disturb its access to the catalytic center of reverse transcriptase, resulting in a decreased inhibition of the enzyme activity.

The effects of the naphthoquinones on the respiration of mitochondria using glutamate as a sub- 
Fig. 4. Effects of the naphthoquinones and sakyomicin A on the oxidation of NADH or NADPH by rat liver mitochondria.

The oxidation of NADH (A) or NADPH (B) by rat liver mitochondria was measured in $3 \mathrm{ml}$ of a basal medium consisting of $225 \mathrm{~mm}$ sucrose, $5 \mathrm{~mm}$ potassium phosphate and $10 \mathrm{~mm}$ Tris- $\mathrm{HCl}(\mathrm{pH} \mathrm{7.4)}$.

Test samples were dissolved in DMSO at $5 \mathrm{mg} / \mathrm{ml}$ and used at the doses indicated in the figure.

The other additions were as follows (stock solution): Mitochondria (M), $1.5 \mathrm{mg}$ as protein; NADH $\left(100 \mathrm{~mm}\right.$ in $\left.\mathrm{H}_{2} \mathrm{O}\right), 1.0 \mu \mathrm{mol}$; NADPH $\left(100 \mathrm{~mm}\right.$ in $\left.\mathrm{H}_{2} \mathrm{O}\right), 1.0 \mu \mathrm{mol}$.

(A)
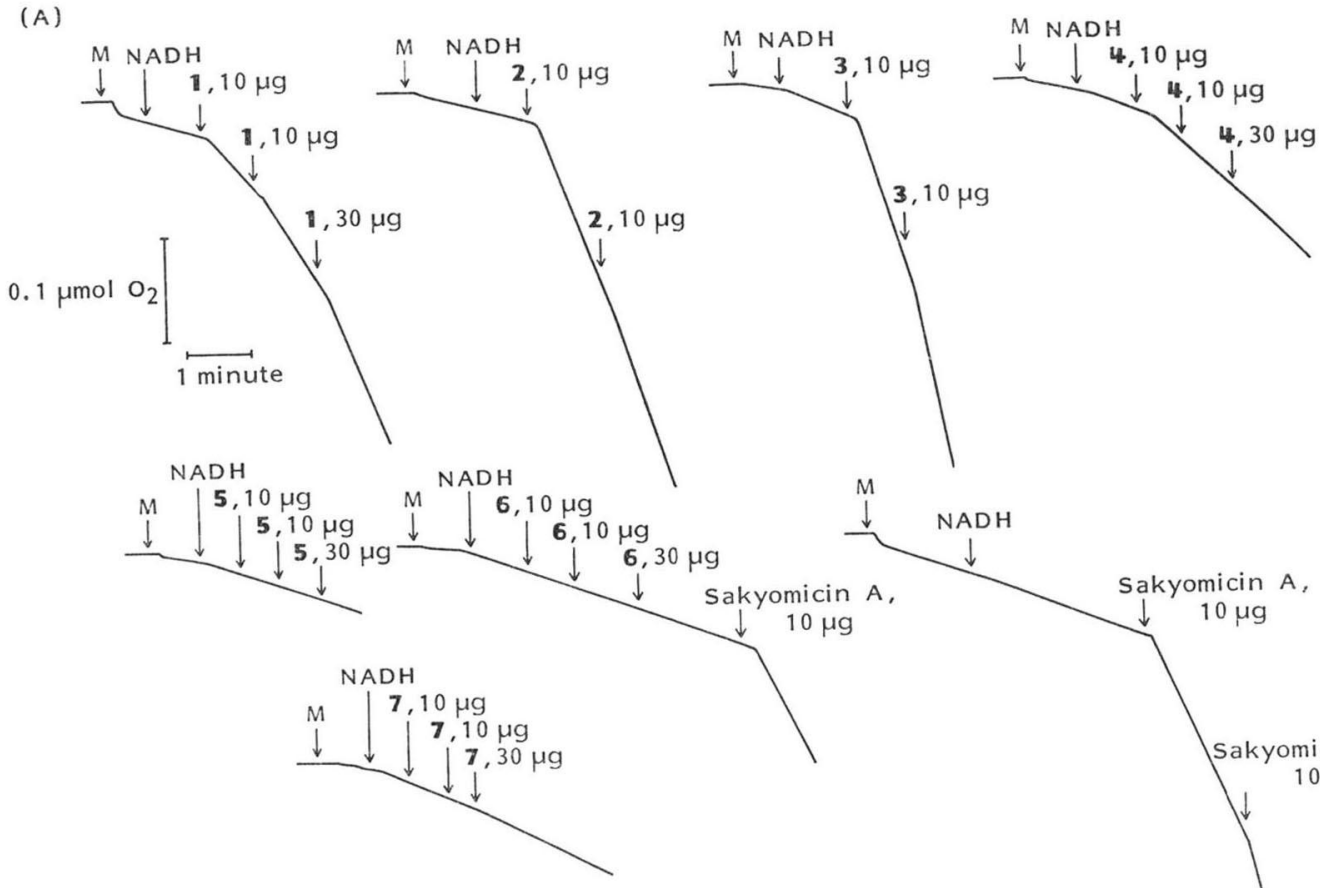

(B)

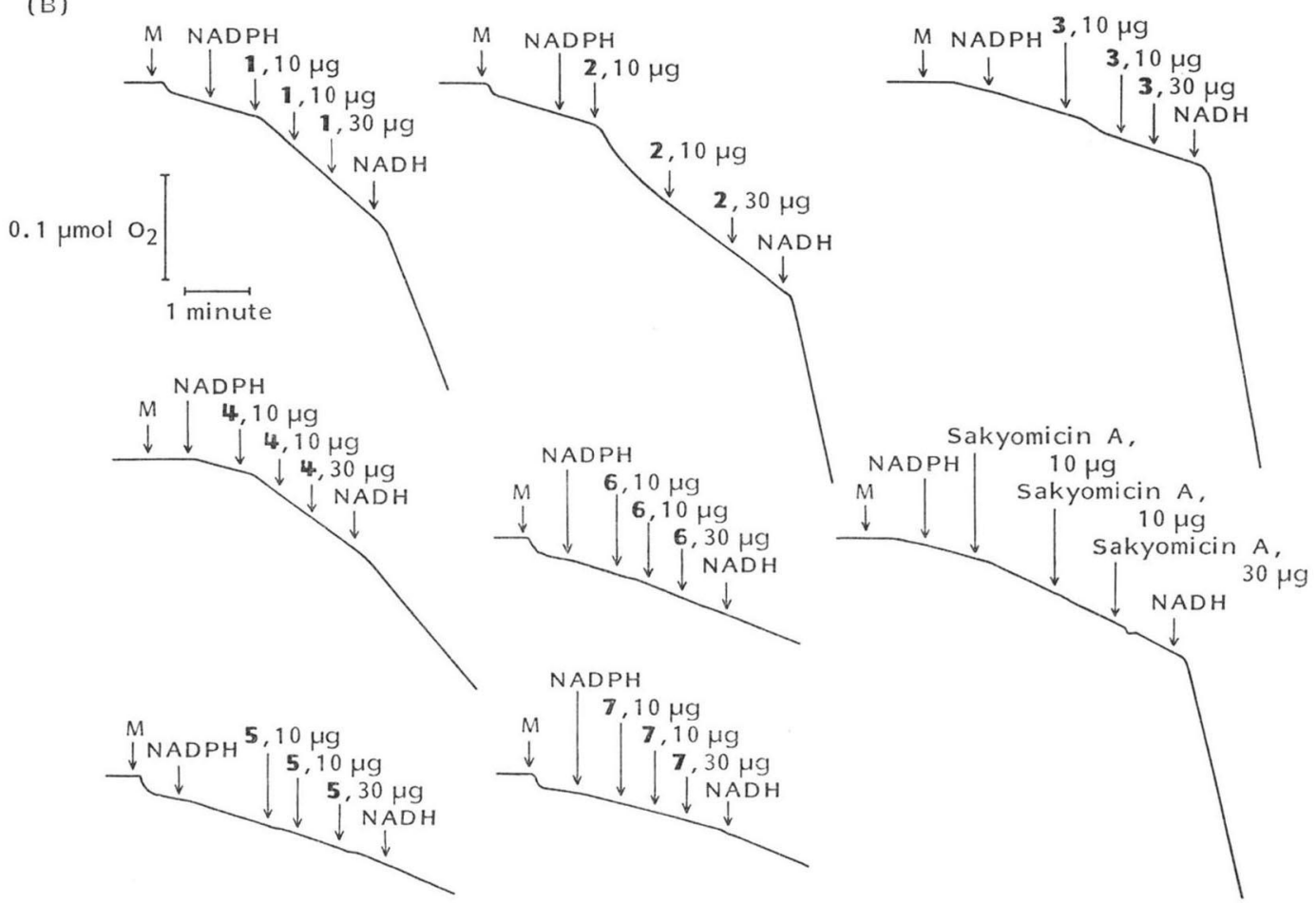


Fig. 5. Effects of the naphthoquinones and sakyomicin A on the oxidation of glutamate by rat liver mitochondria.

Respiration of mitochondria was measured in $3 \mathrm{ml}$ of the basal medium supplemented with $15 \mathrm{~mm}$ glutamate at $30^{\circ} \mathrm{C}$.

Test samples were dissolved in DMSO at $5 \mathrm{mg} / \mathrm{ml}$ and used at the doses indicated in the figure.

The other additions (stock solution): Mitochondria (M), $1.5 \mathrm{mg}$ as protein; $\mathrm{KCN}\left(100 \mathrm{~mm}\right.$ in $\mathrm{H}_{2} \mathrm{O}$ ), $1 \mu \mathrm{mol}$
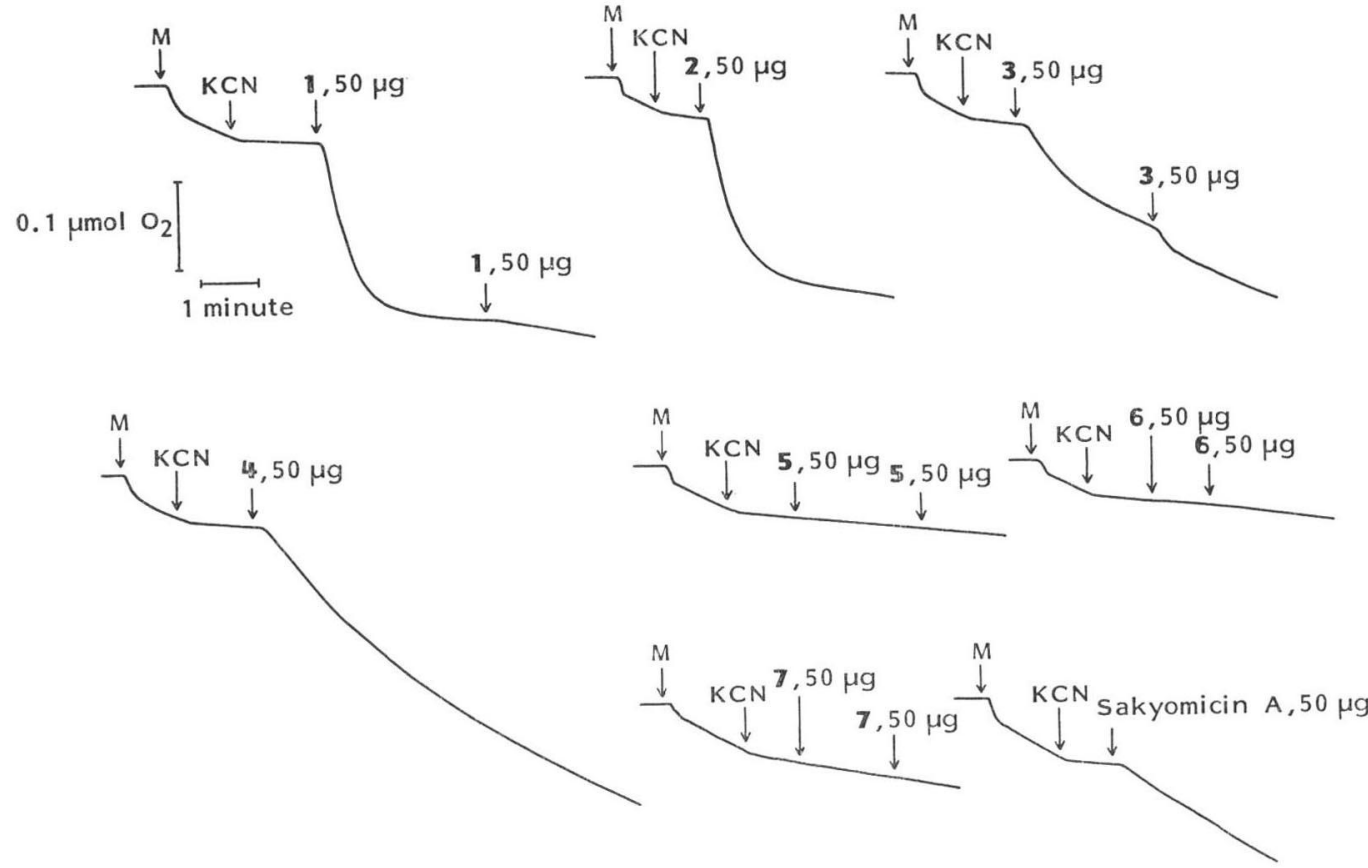

strate were investigated along with that of sakyomicin A. Soon after the addition of $\mathbf{1}$ or $\mathbf{2}$, oxygen consumption in a rapid but not continuous fashion was observed. In contrast, only a trace activity was observed in the presence of sakyomicin A, suggesting its poor membrane transport in mitochondria which might account for a very low cytotoxicity against L5178Y cells. This was beneficial when sakyomicin A was used as an antiviral agent against the in vitro infection of AIDS virus (HTLV-III) as described elsewhere ${ }^{5)}$.

\section{Acknowledgment}

This work was supported in part by a Grant-in-Aid for Cancer Research from the Ministry of Education, Science and Culture, Japan.

\section{References}

1) Nishio, M.; A. Kuroda, M. Suzuki, K. Ishimaru, S. Nakamura \& R. Nomi: Retrostatin, a new specific enzyme inhibitor against avian myeloblastosis virus reverse transcriptase. J. Antibiotics 36: 761 769, 1983

2) Inouye, Y.; N. Manabe, H. Mukai, S. Nakamura, T. Matsugi, H. Amanuma \& Y. Ikawa: Chromostin, a novel specific inhibitor against reverse transcriptase. J. Antibiotics 38: 519 521, 1985

3) Hanajima, S.; K. Ishimaru, K. Sakano, S. K. Roy, Y. Inouye \& S. Nakamura: Inhibition of reverse transcriptase by limocrocin. J. Antibiotics 38: 803 805, 1985

4) Brockmann, H. \& G. Grothe: Über Actinomycetenfarbstoffe. II. Limocrocin, ein gelber Actinomycetenfarbstoffe. Chem. Ber. 86: 1110 1115, 1953

5) Tanaka, N.; T. Okabe, N. Tanaka, Y. Take, Y. Inouye, S. Nakamura, H. Nakashima \& N. Yamamoto: 
Inhibition by sakyomicin A of reverse transcriptase and AIDS-associated virus (HTLV-III/LAV). Jpn. J. Cancer Res. (Gann) (in press)

6) Nagasawa, T.; H. Fukao, H. Irie \& H. Yamada: Sakyomicins A, B, C and D: New quinone-type antibiotics produced by a strain of Nocardia. Taxonomy, production, isolation and biological properties. J. Antibiotics 37: 693 699, 1984

7) InOUYe, Y.; H. OKadA, J. Uno, T. ARAI \& S. NaKamura: Effects of streptonigrin derivatives and sakyomicin A on the respiration of isolated rat liver mitochondria. J. Antibiotics 39: 550 556, 1986

8) OKada, H.; H. MuKaI, Y. InouYe \& S. NAKamuRA: Biological properties of streptonigrin derivatives. II. Inhibition of reverse transcriptase activity. J. Antibiotics 39: 306 308, 1986

9) Chirigos, M. A.; J. W. Pearson, T. S. Papas, W. A. Woods, H. B. Wood, Jr. \& G. Spahn: Effect of streptonigrin and analogues on oncornavirus replication and DNA polymerase activity. Cancer Chemother. Rep. 57: 305 309, 1973

10) Hochstein, P.; J. Laszlo \& D. Miller: A unique, dicoumarol-sensitive, non-phosphorylating oxidation of DPNH and TPNH catalyzed by streptonigrin. Biochem. Biophys. Res. Commun. 19: 289 295, 1965

11) Miller, D. S.; J. Laszlo, K. S. McCarty, W. R. Guild \& P. Hochstein: Mechanism of action of streptonigrin in leukemic cells. Cancer Res. 27: 632 638, 1967

12) KREMER, W. B. \& J. LASZLO: Comparison of biochemical effects of isopropyridine azastreptonigrin (NSC62709) with streptonigrin (NSC-45383). Cancer Chemother. Rep. 51: 19 24, 1967

13) Petrit, G. R. \& L. E. Houghton: Synthesis of hydroxylapachol and lapachol. J. Chem. Soc. (C) 1971: $509 \sim 511,1971$

14) Fieser, L. F. \& M. T. Leffler: Naphthoquinone antimalarials. IV-XI. Synthesis. X. Miscellaneous compounds with oxygen, halogen or nitrogen in the side chain. J. Am. Chem. Soc. 70: 3206 3211, 1948

15) InouYe, Y.; H. OKadA, S. K. Roy, T. Miyasaka, S. Hibino, N. TANaKa \& S. Nakamura: Biological properties of streptonigrin derivatives. I. Antimicrobial and cytocidal activities. J. Antibiotics 38: 1429 1432,1985

16) TRINDER, P.: Determination of glucose in blood using glucose oxidase with an alternative oxygen acceptor. Ann. Clin. Biochem. 6: 24 27, 1969

17) Johnson, D. \& H. LARDY: Isolation of liver or kidney mitochondria. Methods Enzymol. 10: 94 96, 1967

18) Lowry, O. H.; N. J. Rosebrough, A. L. Farr \& R. J. Randall: Protein measurement with the Folin phenol reagent. J. Biol. Chem. 19: 265 275, 1951

19) Uno, J.; M. L. Shigematsu \& T. Arai: Primary site of action of ketoconazole on Candida albicans. Antimicrob. Agents Chemother. 21: 912 918, 1982

20) BALl, E. G.; C. B. ANFinsen \& O. Cooper: The inhibitory action of naphthoquinones on respiratory processes. J. Biol. Chem. 168: 257 270, 1947

21) Wick, M. M. \& G. FitzGerald: Inhibition of reverse transcriptase by tyrosinase generated quinones related to levodopa and dopamin. Chem. Biol. Interact. 38: 99 107, 1981

22) Matsuda, T.; N. Wakamatsu, Y. Inouye, S. Uede, Y. Hashimoto, K. Asano \& S. Nakamura: Purification and characterization of creatine amidinohydrolase of Alcaligenes origin. Chem. Pharm. Bull. 34(5), 1986 